ABAD, 2018; 1(1): 75-88

ISSN: $2618-6004$ abad@ionku.edu.tr

\title{
TÜRK DEVLET YÖNETIMINDE FARKLI BAŞKADILIK UYGULAMALARI: HAZARLAR, ALTIN ORDA VE MEMLÛKLER ÖRNEĞi
}

\begin{abstract}
Mehmet SEKER*
Öz: Türk devlet geleneği içerisinde devlet yönetiminde adlî teşkilatın çok önemli bir yeri ve fonksiyonu bulunmaktaydı. Önceleri adlî teşkilatın bașında Töre'ye göre hüküm veren Yargucu ve yardımcıları varken İslâmiyet'in yayılmaya başlamasından itibaren bu görevlilerin yanında kadılar da bulunmaya bașlamıștır. İslâmiyet'in Türk ülkelerinde hâkim olmasından sonraki dönemde ise durum değișmiș, adlî teșkilatın başında hukukî görevli olarak sadece kadılar kalmıştır. Artık, İslâmî dönem Türk devlet yönetiminde adlî teşkilatın başında hükümdar adına kanunlar tatbik eden en yüksek görevli olan "bașkadı" bulunmaktadır. Biz bu çalıșmamızda üç büyük Türk devletinden hareketle, Türk devletleri içerisinde farklı şekillerde ortaya çıkmış olduğu görülen başkadılık uygulamalarımı ele aldık. Bașkadılık uygulamasının kendine has șekliyle ilk görüldüğ̈̈ Türk devletlerinden birisi hiç kuşkusuz Hazarlardır. Hazarlarda iki Müslüman, iki Yahudi, iki Hıristiyan ve bu üç semavî dine mensup olmayan gruplar ile Slavlar, Rusların davalarına bakan bir başkadı olmak üzere toplam yedi başkadı bulunmaktaydı. İslâmiyet'in hızla yayılmaya bașladığı dönemde büyük bir siyasi hâkimiyete sahip olan Altın Orda Hanlığı'nda başkadılık kurumu kendine özgü bir şekle bürünerek varlık göstermiştir. Altın Orda'da Kurultay'in aslî üyesi olan Yasa Emîri, adlî teşkilâtın başında bulunmakta olup hukukî işlere Töre'ye göre hüküm veren Baș Yargucu ve yardımcılarının yanı sıra İslâm hukukuna göre hüküm veren Başkadı ve yardımcıları bakmaktaydı. Memlûklerde ise Türk-İslâm devletlerinin hiçbirisinde olmayan Sünni dört mezhepten birer bașkadı uygulaması bulunmaktaydı. Bu başkadılardan her birisi kendi mezheplerinden olan kimselerin davalarına bakmaktaydı. İște bu üç büyük Türk devletindeki farklı
\end{abstract}

\footnotetext{
* Dr., Düzce Üniversitesi Fen-Edebiyat Fakültesi, Tarih Bölümü, Düzce/Türkiye, mehmetseker@duzce.edu.tr
} 
Şeker, M. (2018). Türk Devlet Yönetiminde Farklı Başkadılık Uygulamaları: Hazarlar, Altın Orda ve Memlükler Örneği. ABAD, 1(1), 75-88.

başkadılık uygulamalarını inceleyerek Türk devlet sistemindeki adlî teşkilatın dönemin şartlarına ve ihtiyaçlarına göre nasıl sistemli bir şekil alarak tezahür ettiklerini ortaya koymaya çalıştık. Anahtar Kelimeler: Başkadılar, Hazarlar, Altın Orda, Memlûkler

\begin{tabular}{|c|c|c|}
\hline DIVERSIFIED & CHIEF & MUSLIM \\
\hline PLEMENTATIC & DNS & TURKISH \\
\hline $\begin{array}{l}\text { GOVERNMENT: } \\
\text { MAMLUKS EXAM }\end{array}$ & $\begin{array}{l}\text { KHAZARS, } \\
\text { IPLES }\end{array}$ & GOLDEN \\
\hline
\end{tabular}

Abstract: Under the Turkish State tradition, the justice organization had a very important place and function. In the beginning, the justice administration was managed by Yargucu and his assistants who adjudicated according to customs, beginning with the propagation of Islam, a muslim judge proceeded to take part beside these officials. After the next period of Islam's domination of Turkish countries, the situation changed, Muslim Judges ranked among the head of justice admnistration only as legal officers. Muslim Judge was no longer the chief enforcer of law on behalf of the ruler taking part of the head of justice organization in the Islamic period in Turkish state administration. In this work we have discussed via three big Turkish states the diversified chief muslim judge implementations which have emerged differently in Turkish states. One of the first Turkish states is undoubtedly Khazars where the chief Muslim judge implementations have been observed in their own way. In Khazars there were seven chief Muslim judges consisting of two Muslims, two Jews, two Christians and nonmembers of the three monotheistic religious groups such as a Slavic judge who oversaw the cases of the Russians. In the Golden Horde which had a great political dominance at the time when Islam began to spread rapidly, the institution of chief Muslim Judges continued to exist in a distinctive way. In the Golden Horde, Emir was the principal member of congress and at the head of the justice organization, besides the chief Yargucu and his assistants who adjudicated according to custom, there were the chief Muslim Judge and his assistants who adjudicated according to Islamic law who were also responsible for legal affairs. In Mameluke State, there were chief Muslim Judge implementations, one from each four sunni sectarians which was not applied in any of Turkish-Islamic States. Each of these chief Muslim Judges ruled the cases of people who belonged to their own sectarians. Analyzing the three big Turkish States's diversified chief Muslim judge implementations, we tried to reveal how the justice organization in the Turkish 
Şeker, M. (2018). Türk Devlet Yönetiminde Farklı Başkadılık Uygulamaları: Hazarlar, Altın Orda ve Memlükler Örneği. ABAD, 1(1), 75-88.

Government Sytem according to conditions and needs of the period systematically take form.

Keywords : Chief Cadis, Khazars, Golden Horde, Mamluks

\section{Giriş}

Kadl, "hâkim" yani insanlar arasında meydana gelen anlașmazlıkları şer'î hükümlere uygun olarak çözüme kavuşturup neticelendirmek için emretme yetkisine sahip kişi tarafindan tayin olunan görevli kimse demektir (Bilmen, 1985: C. 8, 204). Kadılık, genellikle "hâkim" unvanına denk bir anlamda kullanılmaktadır (Tyan, 1960: 110). Bunun yanında Başkadr (Kâdı'l-Kudât) ise "Kadıların Kadısı" anlamına gelmekte olup hukukun bütün dallarında söz sahibi olan geniş yetkiye sahip kadı demektir (Üner, 1978: 74, 76-77; Özen, 2001: C. 14, 77). Aynı zamanda Başkadı, halife (hükümdar) adına onun yetkisini kullanarak genel olan bütün işlerde özel yetkisi bulunan görevli kimse olarak da tanımlanmaktadır (el-Maverdî, 1989: 29).

Tanımlardan da anlaşılacağı üzere başkadı, devlet yönetiminde en üst makamdaki görevlilerden birisidir. Çünkü bașkadı'yı hükümdarın bizzat kendisi atar, onu atadıktan sonra da başkadıya kendi yetkisinden vererek bașkadı'nın görevlerini yerine getirmesine imkân tanırdı. Bașkadı da hükümdarın yetkisini kullanarak insanlar arasında ortaya çıkan problemleri kanunlara göre çözüme kavuştururdu. Dolayısıyla başkadı, devlet yönetiminde özel yetkisi bulunan üst rütbeli bir devlet görevlisidir.

Başkadılık, dini vazifelerin en büyüğ̈̈ olup derece ve konum olarak en yücesidir (el-Kalkaşandî, 1914: C.4, 35). Halife (hükümdar) adına ülkedeki kanun tatbik etme görevinin en yetkili sorumlusu olan başkadı, aynı zamanda adlî teşkilâtın temsilcisi konumundaydı (el-Maverdî, 1989: 29; Üner, 1978: 76). Başkadıların başlıca görevleri; şer’î hükümlerin uygulanması, kazâi işlerin icra edilmesi, şer’î emirlerin yerine getirilmesi ve hasımlar arasında hüküm verilerek aralarının bulunmasıdır (elKalkaşandî, 1914, C. IV, 34). Ayrıca başkadılık kurumu görev ve fonksiyonları açısından günümüzdeki Adalet Bakanlığına benzemektedir (Yüzbekî,1988: 182).

Başkadılar adlî ve İslâm hukukuyla ilgili işlere bakardı (Tekindağ,1961: 147). Başskadıların görevleri arasında davalara bakarken adaleti gözetme, problemleri çözme, İslâm hukukuna uygun kararlar verme, kamu yararına uygun hareket etme gibi görevler bulunmaktaydı. Bunlara ilaveten 
Şeker, M. (2018). Türk Devlet Yönetiminde Farklı Başkadılık Uygulamaları: Hazarlar, Altın Orda ve Memlükler Örneği. ABAD, 1(1), 75-88.

bașkadılarda dindarlık ve ahlaklılık gibi özellikler de aranırdı (Üner, 1978: 86).

Halifeler hükmettikleri memleketlere daimi kadı atarlar ve bu kadı da emrindeki kimselerden her memleket ve bölge için nâib (vekil/yardımcı) atardı. Atamaları yapan kadı; başkadı diye adlandırılır, bu sıfat sadece onun için kullanılır ve onun dışındakiler ise kadı ya da şu memleketin kadısı diye adlandırılırdı (Üner, 1978: 77-78).

Başkadı, tek başına kendisinin bakamayacağı davalara nâibler tayin ederdi (el-Kalkaşandî, 1914: C.4, 34-35). Dolayısıyla başkadı, her memleket için nâib yani yardımcı görevli tayin ederdi (Üner, 1978: 78). Çünkü başkadı devlet merkezinde bulunmakta olup diğer şehirlerdeki adlî işleri yardımciları vasitasıyla kontrol ederdi.

Türk devlet geleneği içerisinde yerini bulan başkadılık görevi; tarih sahnesine adlarını yazdıran Hazarlar, Altın Orda ve Memlûk devletlerinde farklı uygulamalarıyla dikkat çekmekte olup çalışmamızda bu üç büyük Türk devletinin devleti yönetirken adaletin temini için yaptıkları sistematik uygulamaları ele aldık. Bu üç devletin her birisinin başkadılık uygulaması, özgün bir uygulama sistemi olup gerek kendi dönemlerindeki gerekse kendilerinden sonraki devletlerin hukuki düzenlemelerine tesir etmiş bir düzenlemedir. $\mathrm{Bu}$ sebeple bu üç devletin başkadılık uygulamaları incelenecektir.

\section{Hazarlarda Başkadılık Uygulaması}

Hazarlar 7.-10. yüzyıllarda Karadeniz'in kuzeyinde ve Kafkaslarda hüküm süren büyük bir Türk devletidir. Hazarlar, çok geçmeden büyük bir devlet ve önemli bazı șehirler kurmuștur. Kurulmuș olan bu șehirler, aynı zamanda dönemin en zengin șehirleri arasındaydı (Runciman, 1943: 52). Hazarlar, dinî ve ticarî uygulamaları ile dikkat çektikleri gibi hukukî uygulamaları ile de oldukça dikkat çeken bir devlettir (Ahmetbeyoğlu, 2005: 5).

Kendilerine has idarî bir șekilleri olan Hazarlar, özellikle 7.- 9. yüzyıllar boyunca Doğu Avrupa'da Hazar Barışı (Pax Khazarica) çağı tesis etmiş olup çeşitli dinlere mensup olan tebaasına geniş bir dinî hoşgörü ortamı sunmuștur (Kafesoğlu, 2004: 167, 172).

Hazarlar eski Türk dinî olan Gök Tanrı inancına sahipken sonralanı İslâmiyet, Hıristiyanlık ve Yahudilik dinleriyle tanışmışlardır. Bu dinler zamanla Hazar ülkesinde yayılmıştır. Hazar halkı bu dinlerden hangisine 
Şeker, M. (2018). Türk Devlet Yönetiminde Farklı Başkadılık Uygulamaları: Hazarlar, Altın Orda ve Memlükler Örneği. ABAD, 1(1), 75-88.

mensupsa inandığı dinin inanç ve ibadetlerini ülkelerinde rahat bir ortamda özgürce yerine getirebilmekteydi (Kafesoğlu, 2004: 172).

Hazarlarda bulunan adlî teşkilat içerisinde iki Müslüman, iki Yahudi, iki Hıristiyan ve bu üç semavî dine mensup olmayan gruplar ile Slav, Rusların davalarına bakan bir başkadı olmak üzere toplam yedi başkadı bulunmaktaydı. Bu bașkadılardan ikisi Hazarların hakan ailesinin ve devlet erkânının, ikisi Müslümanların, ikisi Hıristiyanların, birisi bu üç semavî dine mensup olmayan milletler ile Slavların, Rusların adlî ișlerine bakmaktaydı. Dolayısıyla Hazarların hakan ailesinin ve devlet erkânının davalarına bakan başkadılar Yahudi dininden olup Tevrat'a göre hüküm vermekte, Müslüman başkadılar Kur'an'a göre, Hiristiyan başkadılar İncil'e göre ve bu üç semavî dine mensup olmayanlarla Slavların, Rusların davalarına bakan kadı da kendi âdet ve törelerine göre hüküm vermekteydi. Ayrıca bu üç semavî dine mensup olmayan kimseler bilmedikleri önemli meseleler ve çözüme kavuşturamadıkları davalar hakkındaysa Müslümanların başkadılarına müracaat ederlerdi. Bu durumun tabii bir neticesi olarak Hazar ülkesinde adalet ve emniyet hâkim olmuştur (elMes'udî, 1973: C. 1, 179-180; Togan, 1987: C.5/1, 400; Kuzgun, 1985: 94-95). Üç semavî dine mensup olmayan kimselerin meselelerini çözüme kavușturamadıkları zamanlarda Yahudi ve Hıristiyan başkadılara değil de Müslüman başkadılara müracaat etmeleri, devlet kademesinde Müslüman başkadıların öncelikli konumda olduğunu akla getirmektedir.

Hazar Devleti'nde bulunan Müslümanların ekseriyeti Hanefî mezhebinden olup Şâfî mezhebinden olanlar da bulunmaktaydı. Dolayısıyla ülkedeki Müslümanlar Sünni düşünceye hâkimlerdi (Taşağıl, 1998: C. 17, 119). Hazarlarda dinî açıdan çok renkli bir halk tabakası vardı. Diğer Türk devletlerinde olmayan farklı bir dinî ve adlî yapının Hazarlarda mevcut olduğu görülmektedir. Toplum bünyesinde bulunan her dinî grubun kendilerine ait başkadılarının olması o dönemde ileri seviyede bir adlî yapının ve muhakeme usulünün varlığını göstermesi açısından oldukça önemlidir.

Hazar hakan1, komutanlar ve devlet ileri gelenleri Yahudi dinine mensuptu (Şeșen, 2001: 36). Bunun yanı sıra farklı inançların olduğu Hazarlarda, İslâmiyet'in yayılmasıly birlikte toplumun çoğunluğu İslâmiyet'i kabul etmiştir. Hazar halkı arasında Müslümanlığın yayılmasılyla birlikte, devletin adlî sisteminde de bazı değişimler meydana gelmiştir. 
Şeker, M. (2018). Türk Devlet Yönetiminde Farklı Başkadılık Uygulamaları: Hazarlar, Altın Orda ve Memlükler Örneği. ABAD, 1(1), 75-88.

Bu büyük Türk devletinin teşkilat yapısı çok kuvvetli olmakla beraber farklı dinlerin bulunduğu ülkede adliye sistemi de zamanına göre oldukça gelişmiştir. Adlî sistemin çok önemli bir cüzü olan bașkadılık müessesesi de Hazarlarda diğer Türk-İslâm ülkelerinde rastlanmayacak ş̧ekilde kendine has bir özellikle gelișme göstermiştir. Dolayısıyla Türk devlet yönetimi içerisindeki adli sistem içerisinde Hazarlarda bulunan başkadılık sistemi, benzersiz bir uygulamadır diyebiliriz.

Hazarlarda bulunan adlî sistem ve bunun önemli bir cüzü olan başkadılık kurumu daha sonra diğer Türk devletlerindeki kurumlara tesir etmiştir. Bunun en çarpıcı örnekleri Altın Orda ve Çağatay Hanlığı’’nda bulunan adlî sistem ve başkadılık kurumudur.

Netice olarak Hazarların, daha sonraki Müslüman Türk devletlerinde ortaya çıkacak olan hukukî ve örfî meselelere göre hüküm veren mahkemelerin ve kadılık kurumunun ilk uygulayıcılarından olduğunu söyleyebiliriz. Bu yönüyle Hazarlar kendilerinden sonraki Türk-İslâm devletlerine model olmuşlardır.

\section{Altın Orda'da Başkadılık Uygulaması}

Altın Orda Hanlığı (1227-1502) Deşt-i Kıpçak'ta kurulmuş olan büyük bir Türk devletidir (Kafalı, 2005: Mak. 2, 81; Saray, 1989: C. 2, 538). Altın

Orda devlet teşkilatı temelde Türk-Moğol devlet geleneğine dayanmaktadır. Bunun yanında devlet teşkilatında, hâkim olunan bölgelerdeki mahallî uygulamalarda göz önünde bulundurulmuştur (Saray, 1989: C. 2, s. 539). Altın Orda devlet teşkilatında bulunan bu durumun adlî teşkilatta da aynı şekilde olduğu anlaşılmaktadır.

Altın Orda Hanlığı'nda adlî işlerin başında aynı zamanda Kurultay'ın da aslî üyesi de olan Yasa Emîri bulunmaktaydı. Hukukî meselelerde ilk sırada Saray Kadısı da denen Başkadı ve Baş Yargucu ${ }^{197}$ bulunmakta olup bunlar Saray şehrinde oturmaktaydılar. İkinci sırada Sağ-Kol ve Sol-Kol Orda kadıları ve yargucuları bulunmakta, üçüncü sıradaysa şehir kadıları ve yargucuları bulunmaktaydı. Bu iki tür adlî görevli kadrosundan kadılar, İslâm hukukuyla ilgili alanlarda hükmederken yargucular, örf ve âdete ait

197 "Yargucu", "yarg1ç" ya da "savc1 yardımcısı" demektir. Bilindiği üzere Göktürk hükümdarları bazı zamanlar devlet yüksek mahkemesi tertip ederler ve bu mahkemelerde "yargu", "yargan" diye adlandırılan görevli yani yargıç bulunurdu. Bkz. Koca, 2010: 98. 
Şeker, M. (2018). Türk Devlet Yönetiminde Farklı Başkadılık Uygulamaları: Hazarlar, Altın Orda ve Memlükler Örneği. ABAD, 1(1), 75-88.

Töre ${ }^{198}$ ve Yasa hukuku alanında hükmederlerdi (Kafalı, 2002: C. 8, 693; Kafal1, 2005: Mak.1, 140).

Başkadı ve Baș Yargucu, Saray şehrinde oturmakta, Orda kadıları ve yargucularından Sağ-Kol Orda kadıları ve yargucuları Kırım'da otururken Sol-Kol Orda kadıları ve yargucuları ise Harezm'de oturmaktaydılar (Kafalı, 2005: Mak.1, 140).

Altın Orda Hanlığı'nın ilk hükümdarı olan Batu (Sayın) Han'ın (12271256) ölümünden sonra daha önceden Müslüman olmuş Berke Han tahta çıktı (1257/58-1266). Berke Han, Altın Orda Hanlığı'nın ilk Müslüman han'1 olup onun döneminden itibaren devlet giderek İslâmlaşmıștır (Ortayl1, 2017: 95). Berke Han döneminde Altın Orda halkının Müslümanlığ kabul etmesinde Şeyh Necmeddin Kübrâ'nın halifesi Şeyh Seyfeddin Baherzînin rolü büyüktür. Ayrıca Berke Han İslâmiyeti kabul etmesinin ardından Şeyh Seyfeddin Baherzî'nin müridi olmuştur (Kafalı, 2009: 86). Daha sonralan Altın Orda Hanlığı'nın başına geçen Özbek Han'ın (1313-1339) İslâmiyeti kabul etmesinde etkili olan şahısların en başta gelenlerinden birisi Baba Tükles'tir. Aynı zamanda Baba Tükles, Altın Orda halkının Müslümanlığı kabul etmesinde oldukça etkili olmuştur (De Weese, 1994: 67-71). Özbek Han döneminde İslâmiyet adeta devletin resmî dini haline gelmiștir. Bu dönemde animistlere ve Budistlere karșı bir mücadele içerisinde olunmasına karşın ehl-i kitap yani Hıristiyanlık ve Yahudiliğe mensup kimselere karșı mücadele edilmemiștir (Schamiloglu, 2002: C. 8, 719). Bu durum Altın Orda' da semavî dinlere duyulan tolerans1 göstermesi açısından önemlidir. Ayrıca Altın Orda Hanlığı'nda İslâmlaşma sürecinin başlamasının ardından, adlî sistemde birtakım değişim ve dönüşüm de başlamıştır.

Aslında daha önceleri Altın Orda Hanlığı'nda adlî işlere Yargucu ve yardımcıları bakarken İslâmiyet'in bölgeye hâkim olmasından itibarense şer'î davalara kadı'nın, Yasa ve Töre'ye ait olan davalara da Yargucu ve yardımcılarının baktığı görülmektedir. Bu duruma dikkat çeken İbn Battûta, Özbek Han (1313-1339/1340) zamanında Altın Orda Hanlığı'na bağlı olan Harezm ülkesinde görmüş olduğu bir mahkeme meclisinden şöyle söz etmektedir, "Harezm'de Büyük Emir Kutlu Demir'in âdeti olduğu üzere her gün meclisine adlî işleri yerine getirmek üzere kadıyla

${ }^{198}$ Türk topluluklarının hem kamu hukukunun hem de özel hukukunun bütün dallarına ait kanunlarına "Töre" yani "Törü" denir. Bkz. Koca, 2010: 96. 
Şeker, M. (2018). Türk Devlet Yönetiminde Farklı Başkadılık Uygulamaları: Hazarlar, Altın Orda ve Memlükler Örneği. ABAD, 1(1), 75-88.

birlikte fakihler ve kâtipler gelirdi. Ayrıca büyük emîrlerden birisi olan Yargucu ile beraber Türklerin emîrlerinden ve ulularından olan sekiz kișilik yardımcıları da bu mecliste hazır bulunurdu. Yargucu, kadı'nın tam karşısında otururdu. Yargılama sırasında her iki heyet de mecliste hazır bulunurdu. Ele alınan dava şer'î meselelerle ilgiliyse hükmü kadı verirdi. Şayet dava Yasa ve Töre'yle ilgiliyse o takdirde hükmü Yargucu ve yardımcıları verirdi. Onların vermiş oldukları hükümler tutarlı ve adildi. Çünkü onlar ne meylettikleri bir şeyden dolayı suçlanmışlardır ne de rüşvet almışlardır (İbn Battûta, 1992: 362; Kafalı, 2005: 56; Schamiloglu, 2002: C. 8, 721). Görüldüğü üzere Harezm ülkesinde ve bağlı olduğu Altın Orda Hanlığı'nda adlî sistemde yargılamalar bu şekilde olmaktaydı.

İbn Battûta 1333 yılının Ocak ayı civarında Altın Orda topraklarına yapmış olduğu seyahatte, birçok yerde kadıları gördüğünü zikretmektedir. $\mathrm{Bu}$ durumun devlet hayatında, İslâm hukukunun ve kadılık müessesesinin oldukça sistemleşmiş olduğunu akla getirmektedir (Schamiloglu, 2002: C. 8, 719). Ayrıca İbn Battûta Kırım'a bağlı bir şehir olan Kefe'de bir imârethâne de kaldığını ve burada șehrin büyük kadısı olan Hanefi mezhebine göre hüküm veren bir kadı'nın yanı sıra Şâfî mezhebine göre hüküm veren bir Şâfi kadısının da bulunduğunu söylemektedir (İbn Battûta, 1992: 323; Schamiloglu, 2002: C. 8, 719). Sünni mezheplerden Hanefî ve Şâfî mezhebine mensup kimseler, kendi mensup olduklan mezhep kadıları tarafindan yargılanmaktaydı. Bu durum Altın Orda Hanlığı'nın, sosyal hayatta hukukun tatbikinde oldukça ileri bir seviyede olduğunu göstermektedir.

Altın Orda Hanlığı'nda Hanefî mezhebinin daha yaygın olduğu, önemli yargı makamlarına özellikle Hanefî hukukçuların atandığı anlaşılmaktadır. Çünkü Hanefî mezhebi, “örf'ü bir hukuk kaynağı olarak tanımaktaydı. Günlük yaşam içerisinde ortaya çıkan problemlere daha pratik ve esnek çözüm yolları üreten Hanefî hukuku, daha ziyade tercih edilmiştir. Aynı zamanda Hanefî hukuk sistemi, bazı konularda Yasa ve Töre hukukunu da şekillendirmek için de bir firsattı (Krolikowska, 2010: 190).

Altın Orda Hanlığı'nda İslâmiyet'in hızla yayılıp ardından devletin resmi dini haline gelmesinden sonra, gerek Hiristiyan gerekse kamu hayatında varlığını devam ettiren diğer dinlere izin verilmiş ve bu dinlerin müntesiplerine dinî hoşgörü ortamı temin edilerek bu kimseler toplumun bir parçası olarak görülmüștür (Barker, 2014: 156-157). 
Şeker, M. (2018). Türk Devlet Yönetiminde Farklı Başkadılık Uygulamaları: Hazarlar, Altın Orda ve Memlülkler Örneği. ABAD, 1(1), 75-88.

Altın Orda Hanlığı'nda bulunan adlî sistem ve bu sistem içerisindeki başkadılık kurumunun, Türkistan şartlarında da aynı olacağı göz önünde bulundurulduğunda Çağatay Hanlığı'nda da durumun aynı șekilde olduğu varsayllabilir (Kafall, 2005: 56).

Netice olarak diyebiliriz ki Altın Orda Hanlığı'nda bulunan mahkeme ve kadılık sistemi uygulaması, İslâmiyet'in bölgeye hâkim olamaya başladığı bir dönemde şer'î hükümlerin yanında töreyi de göz ardı etmeyen bir yargı uygulaması olarak tezahür etmiştir. Altın Orda Hanlığı kendisinden önceki Hazarlarda bulunan adlî teşkilattan yararlanarak dönemin şartlarına göre bunlara yeni șekiller vermiş olup kendinden sonraki Türk-İslâm devletlerine de tesir etmiştir.

\section{Memlûklerde Başkadılık Uygulaması}

Memlûkler (1250-1517), Orta Çağ da Mısır'da kurulan devletlerarasında en parlak dönemi temsil etmektedir (Durant, t.y: 225). İki buçuk asrı aşkın Misır ve Suriye'de hüküm sürmüş olan Memlûkler, çok zengin bir tarihi mirasa sahip bulunmaktaydılar. Çünkü Memlûkler, bir taraftan Büyük Selçuklular, Zengîler ve Eyyubîler vasıtasıyla Türk Devlet geleneğini, diğer taraftan Abbâsîler vasitasıyla da İslâmî Devlet geleneğini bünyesinde mezcederek Mısır ve Suriye'de siyasi ve kültürel hâkimiyet tesis etmiş büyük bir devletti.

Kendilerine tevarüs eden bu zengin devlet geleneğinin tabii bir neticesi olan başkadılık uygulamasının, Türk-İ̀sâm devletleri içerisinde en dikkat çekici olduğu devletlerden birisi de hiç kuşkusuz Memlûk Devleti'dir.

Memlûklerde dinî kurumların en büyüğü başkadılıktı. Dolayısıyla en yüksek dini görevli de başkadı idi (Tekindağ, 1961:148; Üner, 1978: 86). Hukukî davalara bu bașkadılar bakmaktaydı. Bunun yanı sıra Memlûklerde bazı zamanlar ticaret hukuku ile ilgili davalara hâcibler bakmaktaydı. Örneğin Mısır'a gelen Acem tüccarları; davalarının "şeriat kadılar" tarafından değil, "siyasî müesseseler" tarafından yapılmasını istemișlerdir. Bunun üzerine Memlûkler, bu tüccarların ve memleketler arasında ticaret yapanların (et-tüccâr el-medeniyyûn) hukuki davalarını kadılardan alarak Moğol yargıçları gibi iş gören "siyasî hâcibler"e vermişlerdir (Togan, 1981: 311). Bu durum Memlûklerin, ticaret hukukuna dair meseleler hakkında İslam hukukunun yanı sıra Yasa ve Töre'ye ait hukuku da kadılık sisteminde kullanmış olduklarını göstermektedir.

Memlûkler dönemindeki tarihçiler, İslâm devletlerinde Sünni dört mezhepten başkadıların ilk defa el-Melik ez-Zâhir Baybars tarafından 
Şeker, M. (2018). Türk Devlet Yönetiminde Farklı Başkadılık Uygulamaları: Hazarlar, Altın Orda ve Memlükler Örneği. ABAD, 1(1), 75-88.

tayin edildiğini işaret ederek Baybars'tan önce böyle bir uygulamanın olmadığını kaydederler (el-Kalkaşandî, 1917: C. 11, 174; el-Makrîzî, 1998: C. 3, 390; es-Suyûtî, 2007: C. 2, 84). Dolayısıyla tarihi kaynaklardan anlaşıldığı üzere İslâm tarihinde ilk defa Sünni dört mezhepten başkadılar tayin etme uygulamasını hayata geçiren Memlûk-Devleti'nde Sultan Baybars'tır (Şeker, 2017: S. 82, 168).

Bunun yanında Nüveyrî, İbn el-Kesîr, Kalkaşandî, Makrîzî ve Suyutî gibi müellifler dört mezhep başkadılarının tayin edildiği tarih olarak 663 (12641265) yilında ittifak etmektedirler (en-Nuveyrî, 2004: C. 30, 75; İbn elKesîr, 1998: C. 17, 460; İbn el-Kesîr, 1995: C. 13, 425; el-Kalkaşandî, 1914: C.4, 35; el-Kalkaşandî, 1917: C. 11, 174; el-Makrîzî, 1997: C.2, 2728).

el-Melik ez-Zâhir Baybars, ilk defa başkadı atanması esnasında her kadı için ayrı ayrı görevlendirme fermanı yazmıştı. Şâfi başkadısı kırsal bölgelerde tek sorumluydu. Bunun yanı sıra şehirlerdeyse dört mezhep bașkadılarının görev ve sorumlulukları eșitti. Bu uygulama Baybars'tan sonra da bu şekilde devam etti (el-Kalkaşandî, 1917: C. 11, 174).

Dönemin kaynakları, Mısır'da Sünni dört mezhepten birer başkadı tayin edilmesinin nedenini ayrıntılı biçimde ele alır. Bu başkadılar tayin edilmeden önce Mısır'da o dönemde başkadılık makamında sadece Şâfî mezhebinden Kadı Tâceddin Abdulvehhâb İbn-i Binti'l-E'azz yetkiliydi. Ancak gerek sultan gerekse devlet erkânı Şâfi başkadısının hem verdiği hükümlerin sertliğinden hem de Şâfî mezhebine muvafik olmayan meselelerde çekimser kalıp meseleleri çözüme kavuşturamamasından dolayı ondan rahatsızlardı. Bu yüzden büyük emirlerden birisi olan Emîr Cemâleddin Aydoğdu, el-Melik ez-Zâhir Baybars'ı uyararak diğer mezheplerden başkadılar tayin edilmesinin gerekli olduğunu söyledi (enNuveyrî, 2004: C. XXX, s. 75; el-Kalkaşandî, 1914: C.4, 35; el-Makrîzî, 1997: C.2, 27). Ayrıca Mısır'da Sünni dört mezhep bulunmakta olup adlî iş yükü de oldukça fazlaydı (el-Kalkaşandî, 1922: C. 1, 419; İbn el-Kesîr, 1998: C. XVII, s. 461). Bu durum da dört mezhepten başkadı tayin edilmesinin nedenleri arasındaydı. Çünkü Mısır gibi çok büyük bir ülkede tek başına bir kadı'nın işlerin üstesinden gelmesi mümkün değildi. Aynı zamanda bu durumda çok zaman kaybı da meydana gelmekteydi.

Neticede Baybars, Emîr Aydoğdu'nun teklif ve görüşünü beğenerek Sünni dört mezhep başkadılığ1 uygulamasını hayata geçirdi (İbn el-Kesîr, 1995: C. XIII, s. 425). Baybars'ın yapmış olduğu dört mezhepten bașkadı atama 
Şeker, M. (2018). Türk Devlet Yönetiminde Farklı Başkadılık Uygulamaları: Hazarlar, Altın Orda ve Memlülkler Örneği. ABAD, 1(1), 75-88.

uygulaması, Türk-İslâm devletlerinde sistemli manada bir ilk olma özelliği taşımaktayd.

Tayin edilen dört mezhep başkadılarının her birisi kendi mezhepleriyle alakalı davalarda hüküm verirdi. Ayrıca bu bașkadılar saltanata dair hizmetlerin görüldüğü günlerde kendilerine has turuhât (elbiseler) giyerlerdi (el-Makrîzî, 1997: C. 2, 28). el-Melik ez-Zâhir Baybars'1n her mezhepten birer kâdılkudât ataması İslâm Tarihi'nde orijinal bir durum olarak karşımıza çıkmaktadır (Üner, 1978: 113). Her başkadının kendi mezhebinde olan kimselerin davalarına bakmaları durumu hem hukukî anlamda adalet mekanizmasının daha adil ve daha hızlı bir şekilde çalışmasını sağlamış hem de hukukun tesisinde pozitif katkılar ortaya koymuştur.

Mısır'da dört mezhepten birer başkadı tayin edilmesi uygulamasında olduğu gibi Mısır'dan sonra Şam'da da dört mezhepten birer başkadı tayin edildi (İbn el-Kesîr, 1998: C. 17, 464; İbn el-Kesîr, 1995, C. 13, 427; elKalkaşandî, 1914: C.4, 192; İbn Tağribirdî, 1992: C. 7, 123).

Halep'te de Şam'da olduğu gibi dört mezhepten birer başkadı bulunurdu. Halep'te dört başkadı tayin edilme hadisesi, Şam'da dört başkadı tayin edilmesinden sonra olmuştur (el-Kalkaşandî, 1914: C.4, 221). Bu başkadı tayinlerinde, halkın dini-hukuki inanç ve uygulamaları göz önünde bulundurularak halkın intisap ettiği mezheplere göre kadı tayinleri yapılmıştır. Netice olarak Memlûkler, kendilerinden önce ve kendilerinden sonra hiçbir Türk-İslâm devletinin adlî teşkilatında bulunmayan bir başkadılık uygulaması olan Sünni dört mezhep başkadılık uygulamasını hayata geçirerek orijinal bir bașkadılık sistemi vücuda getirmişlerdir diyebiliriz.

\section{Sonuç}

Türk-İslâm devletlerinde bulunan adalet anlayıșını, İslamî dönem öncesindeki Türk devletlerindeki töre anlayıșı ile İslâmi dönemdeki İslâm hukukunun birlikteliği oluşturmuștur. Adaletle hükmetme meselesi her zaman Türk devlet geleneğinin vazgeçilmez bir vasfi olmuştur. Bunun için gerek Hazarlarda ve Altın Orda devletlerinde gerekse Memlûklerde adalet ve dolayısıyla adalet tesis eden bașkadılık kurumu oldukça gelişmiş bir seviyededir.

Hazarlarda ortaya çıkan adliye teşkilatı ve bunun önemli bir cüzü olan başkadılık uygulaması, kendi dönemi için orijinal bir uygulama olup daha sonraki diğer Türk devletlerine de tesir etmiştir. Hazarlarda adalet tesis 
Şeker, M. (2018). Türk Devlet Yönetiminde Farklı Başkadılık Uygulamaları: Hazarlar, Altın Orda ve Memlükler Örneği. ABAD, 1(1), 75-88.

edilirken sadece belirli bir zümreye ya da ayrıcalıklı bir sınıfa göre hareket edilmemiş, devletin içerisinde bulunan her kesime hitap edecek şekilde bir anlayıș gözetilmiștir. Hazarlarda, iki Müslüman, iki Yahudi, iki Hıristiyan başkadı ve bir de bu üç semavî dinin dışındaki grupların davalarına bakan bir başkadı olmak üzere toplam yedi başkadının bulunduğu uygulama örneği, hiçbir devlette bulunmayan çok farklı bir uygulama olup adaletin tesisi adına çok eşsiz bir örnektir. Ayrıca Hazarlarda bulunan adlî sistemin izleri, Altın Orda, Çağatay Hanlığı vb. Türk-İslâm devletlerinin adlî teşkilatında açıkça görülmektedir.

Hazarlardan etkilenmiş olduğu anlaşılan Altın Orda adlî teșkilatı ve bu meyanda başkadılık uygulaması, kendi dönemi için oldukça ileri seviyede olan bir uygulamaydı. Türk-Moğol devlet geleneğini devrin şartlarına göre mükemmel bir şekilde devlet teşkilatına uyarlayan Altın Orda Hanlığı'nın uygulamış olduğu adlî teşkilat, hem dönemindeki hem de daha sonraki Türk-İslâm devletlerine örnek teşkil etmiştir.

Memlûk Devleti, asırlardan beri süre gelen Türk devlet geleneğini ve aynı zamanda İslâm devlet geleneğini bünyesinde mezcederek mükemmel bir devlet teșkilatı meydana getirmişti. Memlûkler, kendilerine tevarüs eden bu zengin birikimin doğal bir neticesi olarak hem dönemine hem de kendinden sonrasına tesir eden adlî teșkilat ve bunun en önemli unsurlarından birisi olan başkadılık kurumunu vücuda getirmişlerdir. Sünni dört mezhepten başkadılık uygulaması, sistemli olarak Türk-İ̀sâm devletleri içerisinde sadece Memlûklerde bulunan bir uygulamadır. $\mathrm{Bu}$ yönüyle Memlûkler, kendilerine ait çok orijinal bir bașkadılık uygulaması örneği ihdas etmişlerdir.

Netice itibariyle Hazarlar, Altın Orda ve Memlûklerde zamana ve zemine göre hukukun değişkenlik göstermesi prensibi her zaman göz önünde bulundurularak adlî ve hukukî problemler çağın şartlarına göre çözüme kavușturulmuş ve bunun sonucunda da sosyal alanda büyük oranda adalet temin edilmiştir.

\section{Kaynakça}

AHMETBEYOĞLU Ali, Avrupa Hun ve Hazar Devletlerinin iktisadî Gelir Kaynakları, Belleten (2005), C. LXIX, S. 254, s. 5.

İBN Battûta, Rıhle İbn Battûta, Beyrut 1992.

BARKER Hannah, Egyptian and Italian Merchants in the Black Sea Slave Trade;1250-1500, Columbia 2014. 
Şeker, M. (2018). Türk Devlet Yönetiminde Farklı Başkadılık Uygulamaları: Hazarlar, Altın Orda ve Memlükler Örneği. ABAD, 1(1), 75-88.

BİLMEN Ömer Nasuhi, "Hukukı İslâmiyye ve Istılahatı Fıkhiyye" Kamusu, c. VIII, İstanbul 1985.

DEVIN De Weese, Islamization and Native Religion in the Golden Horde: Baba Tükles and Conversion to Islam Historical and Epic Tradition, The Pennsylvania State University Press University Park, Pennsylvania 1994.

DURANT Will, İslâm Medeniyeti, Çev. Orhan Bahaeddin, t.y.

KAFALI Mustafa, "Altın-Orda Hanlığı”, Türkler, c. VIII, Ankara 2002.

"Altın-Orda Hanlı̆̆ı", Makaleler-1 (Haz. Semih Yalçın, Süleyman Özbek), Ankara 2005.

"Altın-Orda Hanlı̆̆ı", Makaleler-2 (Haz. Semih Yalçın, Süleyman Özbek), Ankara 2005.

, Çağatay Hanlığı (1227-1345), Ankara 2005.

, Ötemiș Hacı'ya Göre Cuci Ulusu'nun Tarihi, Ankara 2009.

KAFESOĞLU İbrahim, Türk Millî Kültürü, İstanbul 2004.

EL-KALKAŞANDÎ Ebû el-Abbâs, Subh el-'Așâ fî Sinâ'at el-İnşâ, c. I, Kahire 1992. , a.g.e., c. IV, Kahire 1914.

, a.g.e., c. XI, Kahire 1917.

İBN EL-KESÎR, el-Bidâye ve en-Nihâye, (Tah. Abdullah b. Abdulmuhsin et-Turkî), c. XVII, Misır 1998.

1995.

, Büyük İslâm Tarihi (Çev. Mehmet Keskin), c. XIII, İstanbul

KOCA Salim, Türk kültürünün Temelleri-2, Ankara 2010.

KROLIKOWSKA Natalia, Law and Division of Power in the Crimean Khanate. A Study on the Reign of Murad Giray (1678-1683), Warsaw 2010.

KUZGUN Șaban, Hazar ve Karay Türkleri, Ankara 1985.

EL-MAKRÎZî Takiyy ed-Dîn, el-Mevâ‘iz ve el-İ‘tibâr bi Zikr el-Hitat ve el-Âsâr (Tah. Muhammed Zeynuhum-Medîha eş-Şerkâvî), c. III, Kâhire 1998.

, Kitâb es-Sulûk li Ma'rifet Duvel el-Mulûk (Tah. Muhammed 'Abd el-Kâdir Atâ), c. II, Beyrut 1997.

EL-MAVERDÎ Ebî el-Hasan, Kitâb el-Ahkâmü's-Sultâniyye ve el-Vilâyet ed-Dîniyye (Tah. Ahmed Mübârek el-Bağdâdî), Kuveyt 1989. 
Şeker, M. (2018). Türk Devlet Yönetiminde Farklı Başkadılık Uygulamaları: Hazarlar, Altın Orda ve Memlükler Örneği. ABAD, 1(1), 75-88.

EL-MES'UDÎ Ebî el-Hasan, Murûcu'z-Zeheb ve Meâdinu'l-Cevher (Tah. Muhammed Muhyiddîn Abdulhamid), c. I, Beyrut 1973.

EN-NUVEYRÎ Șehâbüddîn, Nihâyet el-Ereb fî̀ Funûn el-Edeb, (Tah. Necîb Mustafa Fevvâz ve Hikmet Keşlî Fevvâz), c. XXX, Beyrut 2004.

ORTAYLI İlber, Türklerin Altın Çağı, İstanbul 2017.

ÖZEN Şükrü, "Kâdılkudât", İslâm Ansiklopedisi (DİA), c. XXIV, İstanbul 2001.

RUNCIMAN S., Orta Çağların Başlarında Avrupa ve Türkler, Belleten (1943), C. VII, S. 25, s. 52.

ES-SUYÛTÎ Celâleddîn, Hüsn el-Muhâdara fî Ahbâr Mısr ve el-Kâhire, Kahire 2007.

SARAY Mehmet, "Altın Orda Hanlığı" İslâm Ansiklopedisi (TDV), c. II, İstanbul 1989.

SCHAMILOGLU Uli, "Altın Ordu”, Türkler, c. VIII, Ankara 2002.

ŞEKER Mehmet, "Fâtımîlerde ve Memlûklerde Dört Mezhep Başkadılarının Tayini" ,Türk Kültürü ve Hacı Bektaş Velî Araştırma Dergisi, Ankara2017, sy. 82, s.163-170.

ŞEŞEN Ramazan, İslâm Coğrafyacılarına Göre Türkler ve Türk Ülkeleri, Ankara 2001.

İBN TAĞRİBİRDî, Cemâleddîn en-Nücûmu'z-Zâhire fî Mülûki Mısr ve'l-Kâhire, (Tah. Muhammed Hüseyin Şemseddin), c. VII, Beyrut 1992. TAŞAĞIL Ahmet, "Hazarlar" İslâm Ansiklopedisi (TDV), c. XVII, İstanbul 1998.

TEKINDAĞ M.C. Şehabeddin, Şehabeddin, Berkuk Devrinde Memlûk Sultanlığı, İstanbul 1961.

TYAN Emile, Histoire de l'Organisation Judiciaire En Pays d'Islam, Leiden 1960.

TOGAN Zeki Velidi, "Hazarlar" İslâm Ansiklopedisi (MEB), c. V/I, İstanbul 1987.

, Umumî Türk Tarihi’ne Giriş, İstanbul 1981.

ÜNER M. Orhan, Memluklular'da Dinî ve Adlî Kurumlar, (Basılmamış Doçentlik Tezi), Erzurum 1978.

YÜZBEKÎ, Tevfîk Sultân, Dirâse fî en-Nuzum el-Arabiyye ve elİslâmiyye, Bağdat 1988. 